\title{
Bioethanol Production from Sugarcane Bagasse using Fermentation Process
}

\author{
Y. C. WONG* and V. SANGGARI \\ Faculty of Agro Based Industry, University Malaysia Kelantan, \\ Jeli Campus, Locked Bag 100, 17600 Jeli, Kelantan, Malaysia. \\ ${ }^{*}$ Corresponding author E-mail: yeeching@umk.edu.my \\ http://dx.doi.org/10.13005/ojc/300214 \\ (Received: April 10, 2014; Accepted: May 05, 2014)

\begin{abstract}
The aim of this study is to produce bioethanol from sugarcane bagasse using fermentation process and to determine the effect of $\mathrm{pH}$ and temperature on bioethanol yield. Enzymes such as alpha- amylase and glucoamylase were used to breakdown the cellulose in sugarcane bagasse. Saccharomyces cerevisiea, (yeast) also was used in the experiment for fermentation. Five samples were prepared at different $\mathrm{pH}$ was varied to determine the effects of $\mathrm{pH}$ on ethanol yield at $37^{\circ} \mathrm{C}$ and another five samples were prepared to determine the effect of temperature on ethanol yield, the $\mathrm{pH}$ was kept constant at 4.5. The ethanol concentrations were determined by running the samples in High Performance Liquid Chromatography (HPLC). The results showed that at highest ethanol concentration was obtained $\mathrm{pH} 4.5$ and temperature $35^{\circ} \mathrm{C}$. This indicated that $\mathrm{pH} 4.5$ and $35^{\circ} \mathrm{C}$ was the optimum parameter for the yeast to produce ethanol.
\end{abstract}

Key words: Bioethanol, Sugarcane, fermentation, Enzymes.

\section{INTRODUCTION}

Bioethanol is simply ethanol is a renewable energy source which is made by fermenting the sugar and starch components of plant. It is produced from the agricultural product such as corn, sugarcane, potatoes, rice, beetroot and recently using grapes, banana, dates and other wastes. This is due to the decreasing amount of fossil fuels, alternative energy sources need to be renewable, sustainable, efficient, cost effective, convenient and safe $^{2}$.
The demand for oil is expected to increase to $57 \%$ from 2002 to 2030 . The average price of gasoline in 2005 was $\$ 2.56$ per gallon, which was $\$ 0.67$ higher than the average price of gasoline in the previous year. Yet in June 2008, the average price of gasoline in the US reached $\$ 4.10$ per gallon ${ }^{6}$. Rise in energy demand in worldwide and the progressive demising of oil reserves motivate the search for alternative energy resources, especially for those derived from renewable materials such as biomass ${ }^{18}$. 
As a result, they come up ethanol production as substitutes to fossil fuel. The lower cost to produce bioethanol is come from biomass waste because the raw materials are available in abundance.

The main objective of this thesis is to successfully produce bioethanol from sugarcane bagasse. Sugarcane bagasse is an agricultural waste which used to produce bioethanol using fermentation process. Next is to determine the yield of bioethanol produced from sugarcane bagasse. The bioethanol will be determined using HPLC. The highest peck shows the ethanol content. Last objective is to study the effects of temperature and $\mathrm{pH}$ of fermentation process in bioethanol production.

\section{MATERIAL AND METHOD}

\section{Preparation of Sugarcane Bagasse}

The sugarcane bagasse was obtained from area around Tanah Merah and Bazzar Ramadan in Ayer Lanas, Kelantan. The sugarcane bagasse was thoroughly washed with tap water and cut into smaller pieces. Then sugarcane bagasse was dried in oven at $60^{\circ} \mathrm{C}$ for 3 days. It was treated at $60^{\circ} \mathrm{C}$ because if the temperature was higher, it will affect the enzymes in the sugarcane bagasse. Once dried, the sugarcane bagasse was grinded using the grinding machine. The sugarcane bagasse sample was sealed in the seal bag or poly bag and stored in room conditions.

\section{Buffer preparation}

Buffer was used to dilute the enzyme alpha-amylase and glucoamylase. Enzyme reaction will be more effective if dilute with buffer compared to distilled water. There were two types of buffers prepared which were phosphate buffer for $\alpha$ enzymes and acetic acid with sodium acetate buffer for glocoamylase. The prepared buffer was covered with aluminum foil and kept at room temperature for further use.

\section{Liquefaction of sugarcane}

$10 \mathrm{~g}$ of sugarcane was weighed. The weighed sample was placed into conical flask and $200 \mathrm{ml}$ of distilled water was added to the sample. $0.5 \mathrm{ml}$ of $\mathrm{NaOH}$ was prepared to be added at this step to adjust the $\mathrm{pH}$ of the slurry to 4.5 . Next 0.2 microliters of enzyme alpha- amylase was added to the mixture. The alpha-amylase was diluted with phosphate buffer before added to the slurry. The mixture was heated until $50^{\circ} \mathrm{C}$. Alpha- amylases will breakdown the cellulose into smaller size called dextrin.

\section{Saccharifaction of sugarcane bagasse}

The mixture was cooled down to $40^{\circ} \mathrm{C}$. Then, 0.2 microliters of secondary enzyme, glucoamylase was added to the mixture. Glucoamylase was diluted with acetic acid with sodium acetate buffer before added to the slurry. The mixture was maintained at $50^{\circ} \mathrm{C}$ as the glucoamylase hydrolyzed the dextrin to fermentable glucose. The mixture was cooled down to $32^{\circ} \mathrm{C}$ and $10 \mathrm{ml}$ of Saccharomyces cerevisiea (baker yeast) was added to the sample before transferred to conical flask.

\section{Fermentation of sugarcane}

In fermentation process, Saccharomyces cerevisiea (baker yeast) was used to ferment the simple sugar to ethanol and carbon dioxide. To determine the effects of $\mathrm{pH}$ on ethanol yield, the temperature was kept constant at $37^{\circ} \mathrm{C}$ while the $\mathrm{pH}$ was varied from $3,3.5,4,4.5$ and 5 . To determine the effect of temperature on ethanol yield, the $\mathrm{pH}$ was kept constant at 4.5. The fermentation process continued for 48 hours.

\section{Distillation of ethanol}

After 48 hours, the sample was filtered using Whatman Filter Paper to separate the ethanol from the residue. The bioethanol was distilled using rotary evaporator. The sample was heated at $80^{\circ} \mathrm{C}$ to get the bioethanol.

\section{Determine bioethanol yield}

Bioethanol produced was analyzed by high performance liquid chromatography(HPLC). $20 \mu \mathrm{L}$ of the sample was injected into HPLC system to determine the bioethanol yield. Fatty acid composition in virgin coconut oil was analyzed using HPLC method. The HPLC analysis parameters were determined using the following conditions: column, C18 RP (53 x 7mm); injector temperature was $30^{\circ} \mathrm{C}$, $20 \mu \mathrm{L}$ of the sample was injected into the HPLC system. The mobile phase was phosphoric acid and 
the flow rate was $1.5 \mathrm{~mL} / \mathrm{min}$; and detection was set at a wavelength of $210 \mathrm{~nm}$.

\section{Statistical analyses}

The data obtained was subjected to One Way ANOVA using statistical package for social science (SPSS) computer program to find out the significance at $p<0.01$.

\section{RESULTS AND DISCUSSION}

\section{Calibration curve}

In this study calibration cure was drawn to determine total ethanol concentration in water from sugarcane samples. A linear graph of standardization of ethanol was drawn using $95 \%$ ethanol as a standard. The standard was prepared at different concentrations to such as $25 \%, 50 \%$, $75 \%$ and $100 \%$. The amount of ethanol added to each vial showed in the Table 1 . The calibration equation of ethanol standard was determined to be $y=367.94 x-2853\left(R^{2}=0.9515\right)$ where $y$ is the peak area of ethanol and $x$ is the concentration of ethanol. The Ethanol standard curve is shown in the Figure 1.

\section{Effects of $\mathrm{pH}$ of fermentation process on ethanol concentration in water}

The study was carried out to determine the significant influences of $\mathrm{pH}$ on fermentation due to its effect on yeast growth and fermentation rate. The sample was fermented at different $\mathrm{pH}$ values

Table 1: Standard calculation

\begin{tabular}{cccc}
\hline $\begin{array}{c}\text { Concentration } \\
(\%)\end{array}$ & $\begin{array}{c}\text { Volume of ethanol } \\
\text { Standard }(\mathbf{m l})\end{array}$ & $\begin{array}{c}\text { Volume of mobile } \\
\text { phase }(\mathbf{m l})\end{array}$ & $\begin{array}{c}\text { Peak } \\
\text { Area }\end{array}$ \\
\hline 25 & 0.5 & 1.5 & 5229 \\
50 & 1.0 & 1.0 & 15330 \\
75 & 1.5 & 0.5 & 28520 \\
100 & 2.0 & 0 & 31494 \\
\hline
\end{tabular}

Table 2: The Effects of $\mathrm{pH}$ on Ethanol Concentration (\%) in water

\begin{tabular}{lc}
\hline pH & Ethanol concentration in water (\%) \\
\hline 3.0 & 10.7 \\
3.5 & 11.6 \\
4.0 & 11.9 \\
4.5 & 14.8 \\
5.0 & 0.0 \\
\hline
\end{tabular}

Table 3: Effects of temperature on ethanol concentration in water (\%)

\begin{tabular}{lc}
\hline $\begin{array}{l}\text { Temperature } \\
\left({ }^{\circ} \mathrm{C}\right)\end{array}$ & $\begin{array}{l}\text { Ethanol concentration } \\
\text { in water with water }(\%)\end{array}$ \\
\hline 25 & 0.0 \\
30 & 0.0 \\
35 & 13.7 \\
$40]$ & 12.3 \\
45 & 11.1 \\
\hline
\end{tabular}

from 3, 3.5, 4, 4.5 and 5 while the temperature was kept constant at $37^{\circ} \mathrm{C}$ to obtain maximum yield of bioethanol. The total bioethanol content in each sample was determined and recorded in the Table 2 and Figure 2.

Based on the results obtained, $\mathrm{pH} 4.5$ showed the highest ethanol content in water which is $14.8 \%$, followed by $\mathrm{pH} 4.0$ which is $11.9 \%$, then $\mathrm{pH} 3.5$ at $11.6 \%$ and $\mathrm{pH} 3.0$ at $10.7 \%$. The lowest ethanol concentration in water with water was achieved at $\mathrm{pH}$ 5.0. Figure 4.1 show that the ethanol concentration in water gradually increases along with the increases in $\mathrm{pH}$ and reaches a maximum percentage of ethanol production when $\mathrm{pH}$ is equals to 4.5 and later it start to declining.

The maximum ethanol concentration in water at $\mathrm{pH} 4.5$ reflects enzyme function in an environment ${ }^{1}$ while the lower ethanol concentration in water at $\mathrm{pH}$ reflects lesser yeast activity. The maximum ethanol productivity was observed at $\mathrm{pH}$ 
of 4.2 to $4.5^{3,12}$. Furthermore, the increase in ethanol concentration in water is more efficient with the increase in $\mathrm{pH}$ from 4.0-4.5 and also found that the optimum $\mathrm{pH}$ range for S.cerevisiae to be $\mathrm{pH} 4.5^{22}$.

In general, yeast is an acidophilic organism and as such, grows better under acidic condition. The optimum $\mathrm{pH}$ range for yeast growth can vary from $\mathrm{pH} 4.0$ to 6.0 , depending on the temperature, the presence of oxygen and strain of yeast. Optimum $\mathrm{pH}$ values are required for the activity of plasma membrane bound proteins, including enzymes and transport proteins ${ }^{10}$. During growth, it is important for the yeast to maintain a constant intercellular $\mathrm{pH}$.

There are many enzymes functioning during within yeast cell during growth and its metabolism. Each enzyme works best at its optimal $\mathrm{pH}$, which is acidic because of the acidophilic nature of the yeast itself. When the extracellular enzymes $\mathrm{pH}$ changes from the optimal level, the yeast cell required using energy to either pump in or pump out the hydrogen ions in order to maintain the optimum intercellular $\mathrm{pH}^{11}$.

If the extracellular $\mathrm{pH}$ changes too much from the optimum $\mathrm{pH}$ range, it may too difficult for the cell to maintain constant intracellular $\mathrm{pH}$ and the enzyme may not function normally. Furthermore, if the enzymes are deactivated, the yeast cell will not be able to grow and make ethanol efficiently ${ }^{10}$.
This is the most likely explanation for the observed reduction in ethanol production when the initial medium $\mathrm{pH}$ was at 3.0. There were also low carbon dioxide productions at $\mathrm{pH} 3$ because the low $\mathrm{pH}$ encourages the production of acid instead of alcohol $^{5}$.

However this study shows lowest ethanol concentration in water at $\mathrm{pH} 5$. This may be due to the disability of the yeast strain to tolerate at $\mathrm{pH} 5$. Different yeast strain has different $\mathrm{pH}$ range to activate and produce ethanol. There are other possibilities; the yeast that was used to conduct the experiment may be old. Old yeast will not carry out fermentation process efficiently compared to new yeast. According to Misonoet al. (1990) [9], there is increased rate of ethanol production at $\mathrm{pH}$ 5. This statement is not applicable for this study since at $\mathrm{pH} 5$ there is no ethanol production.

\section{Effects of temperature of fermentation process on ethanol concentration in water}

Temperature is one of the major factors that determine the ethanol production. Table 3 and Figure 3 showed the ethanol concentration in water (\%) that obtained at different temperature. Based on the result obtain, no ethanol concentration in water was observed at 25 and $30^{\circ} \mathrm{C}$.

However, as the temperature increases beyond $30^{\circ} \mathrm{C}$ it showed increase in production of

Table 4: Summary for one way ANOVA table for effect of $\mathrm{pH}$ and ethanol concentration

\begin{tabular}{lccccc}
\hline \multirow{2}{*}{ Ethanol } & \multicolumn{5}{c}{ ANOVA } \\
\cline { 2 - 5 } concentration & Sum of Squares & df & Mean Square & F & Sig. \\
\hline Between Groups & 447.149 & 4 & 111.787 & 84.051 & .000 \\
Within Groups & 13.300 & 10 & 1.330 & & \\
Total & 460.449 & 14 & & \\
\hline
\end{tabular}

Table 5: Summary for ANOVA table for effect of temperature and ethanol concentration

\begin{tabular}{lccccc}
\hline \multirow{2}{*}{ Ethanol } & \multicolumn{5}{c}{ ANOVA } \\
\cline { 2 - 5 } concentration & Sum of Squares & df & Mean Square & F & Sig. \\
\hline \multirow{2}{*}{ Between Groups } & 487.620 & 4 & 121.905 & 14.384 & .000 \\
Within Groups & 84.753 & 10 & 8.475 & & \\
Total & 572.373 & 14 & & \\
\hline
\end{tabular}


ethanol. At $35^{\circ} \mathrm{C}$ ethanol concentration in water were maximum and turned out to be $13.7 \%$ followed by $40^{\circ} \mathrm{C}$ where $12.3 \%$ ethanol was obtained. Fermentation process required a suitable

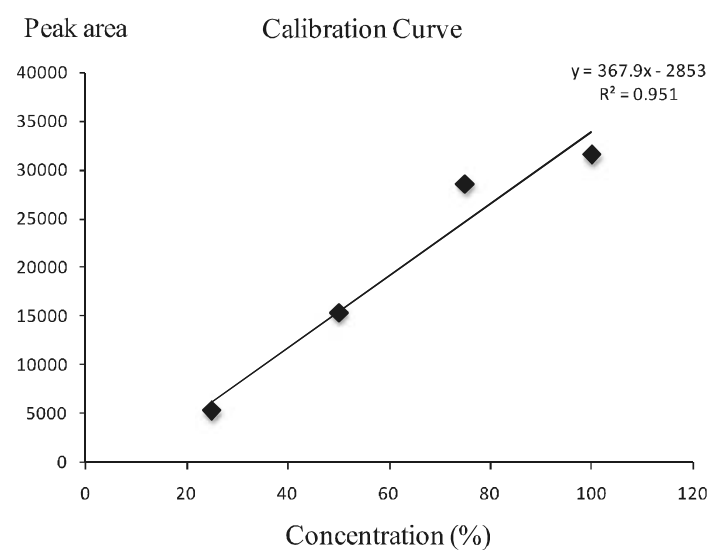

Fig. 1: Ethanol Standard Curve

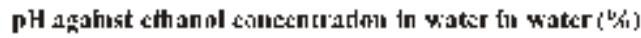

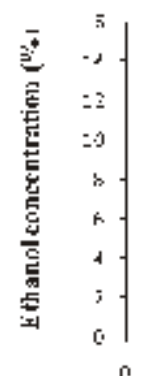

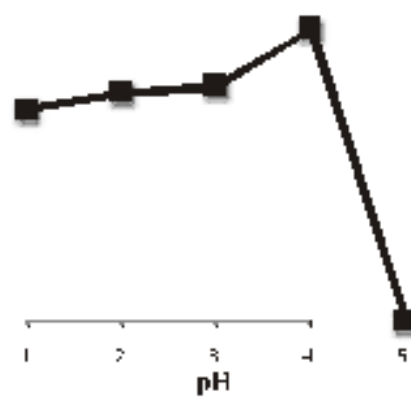

Fig. 2: Effect of pH against ethanol concentration in water

Temperature against Ethanol concentration in water (thi

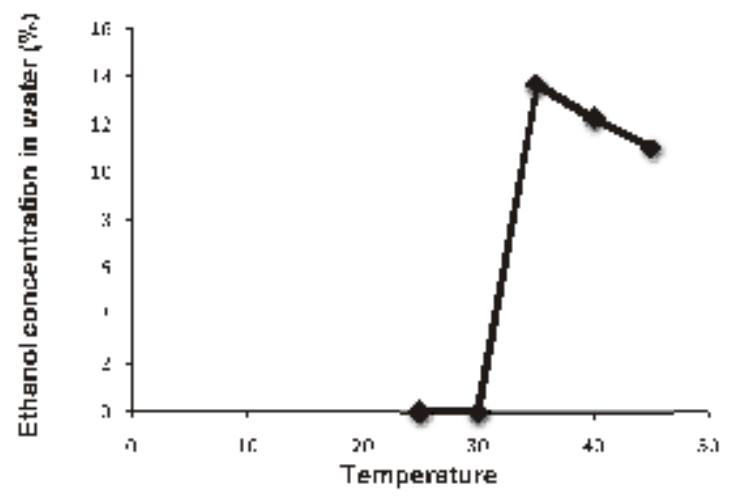

Fig. 3: Effect of temperature against ethanol concentration in water temperature for the yeast to react ${ }^{16}$. Temperature that is too high kills yeast, and low temperature slows down yeast activity. Thus, to keep a specific range of temperature were required.

However the ethanol concentration in water was decreased at $45^{\circ} \mathrm{C}$. This indicates that $35^{\circ} \mathrm{C}$ were the optimum temperature for ethanol production. This finding is in agreeable with last studies about temperature on ethanol concentration in water ${ }^{14-15,17}$. This studies result also denied the study of Yah et al., (2010) [23], who found optimum temperature of ethanol production to be $25^{\circ} \mathrm{C}$.

From the result we can conclude that higher the temperature, lower the ethanol concentration. The rate of enzyme catalyzed reaction increases with temperature up to a certain temperature and then the enzymes begins to denature. Higher temperature inhibits the growth of the cells and fermentation significantly decreases. In this study, ethanol concentration in water declined considerably at $40^{\circ} \mathrm{C}$, which showed the inhibition effects on the cell growth at higher temperature.

This statement supported by study from ${ }^{8,13}$. Based on the high temperature might denature the ribosome and enzymes. Furthermore, higher temperature would alter the structure of the membrane and decreases its functionality ${ }^{7}$. Above the optimum temperature, the enzyme reaction drops precipitously as the enzyme denatures ${ }^{19}$.

Enzymes are sensitive to temperature changes. At temperature above $40^{\circ} \mathrm{C}$ the rate of respiration slows down and drops. This was because all the enzymes are made up of the protein chains of amino acid. It exists in the form of a helix structure with hydrogen bonds holding them together. When heat was applied to the enzyme, energy was given off. The active enzyme cell deforms and the hydrogen bonds break, denature the yeast enzyme. This process called as denaturizing. The optimum temperature in which yeast enzyme work best is around $35^{\circ} \mathrm{C}$, below this temperature the rate of reaction was slow and above $45^{\circ} \mathrm{C}$ the yeast enzyme would denature.

At low temperature the cells showed no ethanol concentration. This may be due to enzymes low tolerance to produce ethanol at lower 
temperature ${ }^{4,21}$. Furthermore, at low temperature the enzyme deactivated and reaction slow down or stop altogether ${ }^{20}$. At lower temperature, the molecules move slower than at higher temperature. These explain that the enzyme may not have enough energy to cause chemical reaction. Overall we can conclude that temperature $35^{\circ} \mathrm{C}$ was the optimum temperature for ethanol production.

Statistical analysis for effects of $\mathrm{pH}$ and temperature on fermentation process

One way analysis of variance (ANOVA) was conducted to evaluate the relationship between effects of $\mathrm{pH}$ on ethanol concentration. The Independent values were $\mathrm{pH}$ while the dependent values were ethanol concentration. AVOVA used determine whether there was a significance difference in ethanol concentration. Table 4 shows the ANOVA table for the effect of $\mathrm{pH}$ on ethanol concentration. The one way ANOVA results indicate that there was a significant difference in $\mathrm{pH}$ at $(P<0.01)$ level for three conditions $[F(4,10)=84.051$, $\mathrm{p}=0.000]$.

One way analysis of variance (ANOVA) was conducted to evaluate the relationship between effects of temperature on ethanol concentration. The independent values were temperature while the dependent values were ethanol concentration. AVOVA used determine whether there was a significance difference in ethanol concentration. Table 5 shows the one way ANOVA table for the effect of temperature on ethanol concentration. The one way ANOVA results indicate that there was a significant difference in temperature at $(P<0.01)$ level for three conditions $[F(4,10)=$ $14.384, p=0.000]$.

\section{CONCLUSION}

This study shows that $\mathrm{pH} 4.5$ showed the highest ethanol content in water which is $14.8 \%$, followed by $\mathrm{pH} 4.0$ which is $11.9 \%$, then $\mathrm{pH} 3.5$ at $11.6 \%$ and $\mathrm{pH} 3.0$ at $10.7 \%$. The lowest ethanol concentration in water with water was achieved at $\mathrm{pH}$ 5.0. The study also shows that at $35^{\circ} \mathrm{C}$ ethanol concentration in water were maximum and turned out to be $13.7 \%$ followed by $40^{\circ} \mathrm{C}$ where $12.3 \%$ ethanol. However there is no ethanol production at temperature 25 and $30^{\circ} \mathrm{C}$. Statistical analysis one way ANOVA results indicate that there was a significant difference in $\mathrm{pH}$ at $(\mathrm{P}<0.01)$ level for three conditions $[F(4,10)=84.051, p=0.000]$. The one way ANOVA results for temperature indicate that there was a significant difference in temperature at $(P<0.01)$ level for three conditions $[F(4,10)=14.384$, $p=0.000]$. Further study should conduct on more parameter that effect the fermentation process on ethanol production. There are other parameter such as amount of subtract, time and glucose concentration which affects ethanol production during fermentation. This will gives the overall view how ethanol production affected. In conclusion, $\mathrm{pH}$ 4.5 and $35^{\circ} \mathrm{C}$ is the optimum condition for ethanol production.

\section{ACKNOWLEDGEMENTS}

The authors express their sincere thanks to University Malaysia Kelantan (UMK) for the financial support and providing the necessary facilities for the successful completion of this research work.

\section{REFERENCES}

1. Berg, J.;Biochemistry, sixth ed. Freemantle and Company, London, 2007.

2. Chum, H. L.; Overend, R. P.;Fuel Processing Technology, 2001, 71, 187-195.

3. De Vasconcelos, J. N.; Lopes, C. E.; de França, F. P.;International Sugar Journal,1998,100, 73-75.

4. Gao, C.; Fleet, G. H; Journal of Applied Bacteriology, 1988,65, 405- 410.
5. Jennings, D.H.; The physiology of Fungal Nutrition. Cambridge University Press, Cambridge,1995, 392-394.

6. Kumar, P.; Barrett, D. M.; Delwiche, M. J.; Stroeve, P.;Industrial and Engineering Chemistry Research,2009, 48, 3713-3729.

7. Lucero, P.; Peñalver, E.; Moreno, E.; Lagunas, R.;Applied and Environmental Microbiology,2000, 66, 4456- 4461. 
8. McMeckin, T. A.;Olley, J.;Ratkwsky, D. A.; Ross, T; International Journal Food Microbiology, 2002, 73, 395-407.

9. Misono, H. M.; Yamaguchi, Y.;Journal of Fermentation Technology,1990,8, 210-218.

10. Narendranath, N. V.,;Power, R.;Applied and Environmental Microbiology, 2005, 71, 2239-2243.

11. Narendranath, N. V.; Thomas, K. C.; Ingledew, W. M.;Journal of the American Society of Brewing Chemists, 2001,59, 187-194.

12. Nigam, J. N.;Journal of Biotechnology,1999, 72, 197-202.

13. Phisalaphong, M.; Srirattana, N.;Tanthapanichakoon, W.; Biochemistry Engineering Journal, 2006, 28, 36-43.

14. Pramanik, K.;Institution Chemistry Engineers, 2003,34, 487-492.

15. Redzepovic, S.; Orlic, S.; Sikora, S.; Majdak, A.; Pretorius, I. S.; WhileyInterscience Journals,2002, 350.
16. Rivera, M.; Cardona, C. A.;Ingenier1'a y Competitividad, 2006,6, 17-25.

17. Roehr, M.; The Biotechnology of Ethanol: Classical and Future Applications. Chichester: Wiley-VCH., 2001, 232.

18. Saxena, R. C.;Adhikari, D.K.; Goyal, H.B.;Renewable and Sustainable Energy Reviews, 2009,13, 167-178.

19. Southerland, W. M.; Foundations of Medicine: Biochemistry, Churchill Livingstone. Inc., New York, 1990.

20. Togarepi, E.; Mapiye, C.; Muchanyereyi, N.; Dzomba, P.; International Journal of Biochemistry Research \& Review, 2012,2(2), 60-69.

21. Torija, M.J.; Roze‘s, N.; Poblet, M.;Guillamo'n, J. M.; Mas, A.;Antonie van Leeuwenhoek, 2003,79, 345- 352.

22. Yadav, B. S.;Sheoran, A.; Rani, U.; Singh, D.;Indian Journal Microbiology,1997,37, 6567. 